\title{
Comparison of Arbuscular Mycorrhizal Spores Abundance Under Sengon (Falcataria moluccana (Miq.) Barneby \& Grimes) Planted on Deep Peat and Mineral Soils
}

\author{
Tri Wira Yuwati ${ }^{1}$, Wanda Septiana Putri ${ }^{2}$, and Badruzsaufari ${ }^{2}$ \\ ${ }^{1)}$ Banjarbaru Environment and Forestry Research and Development Institute, Indonesia \\ $\left.{ }^{2}\right)$ Faculty of Mathematics and Natural Science, Lambung Mangkurat University, Indonesia \\ Correspondence email : yuwatitriwira@gmail.com
}

\begin{abstract}
Mycorrhizae are known as soil fungi because of their habitat in the rooting area (rhizosphere). Nearly $97 \%$ of terrestrial plant species interact or symbiotic with mycorrhizae. Symbiosis is formed in the form of an exchange between nutrients and carbohydrates and helps plants absorb P. elements. In Kalimantan, sengon often used as industrial material because it is fast-growing species and widely cultivated by the community. Sengon is a common species planted in mineral soils; however, due to the rising demand of sengon timber, it has been planted on peatlands. This study aims to compare the abundance of arbuscular mycorrhizal spores and identify the morphology of arbuscular mycorrhizal spores associated with Sengon planted on peatlands and mineral soils. This study used a wet sieving method and root staining from the modification of Vierherling et al. 1996 and calculation of root mycorrhizal colonization with gridline techniques. The research used the normality test of data distribution and the T test (Independent sample T test) to determine trends and comparison of differences in the abundance of FMA spores. The study results showed a significant difference in the abundance of AMF in the form of colonization by calculating the percentage of AMF colonization in the sengon root in mineral soils and peatlands of $23.56 \% 41.67 \%$, respectively. The spore density on mineral soils and peatlands were 18.05 / 50gr and 1.09 / $50 \mathrm{gr}$, respectively. Identification results showed that there were four genera found in peat soil locations, namely the genus Glomus, Gigaspora, Scutellospora, and Acaulospora, while in the mineral soil were found three generas namely genus Glomus, Scutellospora, and Acaulospora. Out of the four generas, the most abundant in both soil types was Glomus.
\end{abstract}

Keywords: Arbuscular Mycorrhizal Fungi, Spores, Sengon, Peatland, Mineral soil

\section{INTRODUCTION}

Arbuscular mycorrhiza is a symbiotic mutualism between soil fungi and plant's roots (Harley and Smith, 1983). The term of symbiosis is used to describe the dependent mutualistic relationship between the fungi which receives photosynthetic carbon from the host plant, and the host plant, which receives soil nutrients, particularly phosphorus, water and protection from root pathogens and toxic elements (Brundrett et al., 1996; Harley and Smith, 1983; Dell, 2002; Rillig, 2004). Arbuscular Mycorrhiza Fungi (AMF) is part of Zygomycota family developing arbuscular structures, hyphae, and vesicles inside the plant root cortex cells (Brundrett et al., 1996). According to Husna et al., (2007), almost $97 \%$ of the terrestrial plants associated with AMF. AMF has many benefits. It enhances water absorption and drought tolerance (Auge, 2001), enhances the mobilization and nutrient transfer (Brundrett et al., 1996), enhances plant's tolerance to salinity (Sheng et $a l ., 2009$ ) and increases the capacity in phosphate absorption compared with non-mycorrhizal roots (Plassard \& Dell, 2010). Nurbaity et al., (2009) stated that these fungi could be utilized as an alternative technology to assist plant growth, enhance productivity, and increase plants' quality on marginal lands. 
Sengon (Falcatharia moluccana (Miq.) Barneby \& Grimes) is one of the fast-growing species that grows, especially on mineral soils, and used to be planted on marginal lands (Krisnawati et al., 2011). Sengon is able to grow in various soils ranging from poor drainage to rich nutrient soil (Baskorowati, 2014). Furthermore, Krisnawati et al., 2011 stated that Sengon is a pioneer species of multi-purpose tree species in Indonesia. Sengon has a promising economic value. It is one of the reasons of Sengon development in Kalimantan. Not only on mineral soils, nowadays, in the shallow peat and also deep peat of Central Kalimantan province, Sengon are planted. Since the establishment of a timber factory in Pulang Pisau district, a province with more than $60 \%$ of the area is peatland; the community is encouraged to plant Sengon to supply the timber factory.

Yuwati and Hakim (2018) carried out a study on the relationship between arbuscular mycorrhiza and Sengon roots grown on shallow peat of South Kalimantan. The result of the study showed that arbuscular mycorrhiza fungi were able to form colonization with sengon roots with an average colonization of $61 \%$. There were four generas of arbuscular mycorrhiza spores found underneath sengon, including Glomus sp., Gigaspora sp., Scutellospora sp., and Acaulospora sp (Yuwati and Hakim, 2018). The same generas of arbuscular mycorrhiza spores were also found under the Shorea balangeran trees planted on deep peat (Yuwati and Putri, 2020). Furthermore, (Yuwati and Putri, 2020) concluded that arbuscular mycorrhiza spores can be used as bio-indicator for the revegetation success in peatland. It was found that the older Shorea balangeran trees, the higher number of spores underneath. Study of Yuwati et al., (2020) on the abundance of arbuscular mycorrhiza infective propagules under Galam (Melaluca cajuputi) at shallow peat of South Kalimantan showed there were 55,667 - 85,113 propagules per 50 gram soil and the roots colonization was ranging from 57-70\%. Hermawan et al., (2015) studied the abundance of arbuscular mycorrhiza fungi under Eucalyptus pellita planted in peatland of West Kalimantan. The study concluded that the number of spores was higher, the deeper the peat.
Information on the abundance of arbuscular mycorrhiza spores is needed as a way to determine the inoculum potential. Inoculum potential is a specific amount of arbuscular mycorrhiza inoculum to cause root infection under a standard set of conditions (Luo and Liu, 1994). In order to determine the benefit of arbuscular mycorrhiza under sengon trees grown in deep peat and mineral soils, this paper has two objectives: 1) compare the abundance of arbuscular mycorrhiza spores under sengon grown on deep peat and mineral soils; 2) to compare the morphological characteristics of arbuscular mycorrhiza spores under sengon grown on deep peat and mineral soils.

\section{METHODS}

\section{Soil and root sampling}

The research was carried out June- October 2019 at the Forest Microbiology Laboratory, Banjarbaru Environment and Forestry Research and Development Institute, Banjarbaru, South Kalimantan. Mineral soil sampling was conducted at KPH Pelaihari, Tanah Laut, South Kalimatan, while peat soil sampling was conducted at KHDTK (Forest for Specific Purpose) Tumbang Nusa, Central Kalimantan. Soil sample collection was conducted by digging with soil auger at two soil depths: $0-30 \mathrm{~cm}$ and $30-60 \mathrm{~cm}$. Approximately 200 gram of soil was taken at each depth. There were three-hole replications for each depth for one tree. The soil samples were taken under three trees for each soil type (mineral soil and peat soil).

\section{Sengon root colonization assessments}

Roots were separated from the soil samples. Root staining method that was used following Vierheilig (1996). Roots were cleared under tap water. Roots were then soaked in $\mathrm{KOH} 10 \%$ solution for \pm 24 hours. KOH $10 \%$ solution was then removed, roots were cleared under tap water, and rinsed. The cleared roots were then soaked in HCL $0,1 \mathrm{~N}$ solution for \pm 24 hours; the solution was then removed, cleared under tap water, and soaked in solution of Parker ink and 5\% acetic acid (vinegar) for \pm 24 hours. The roots were rinsed and cut into $1 \mathrm{~cm}$ size. Each root piece were placed on petridish and observed under 
stereomicroscope using Gridline Intersect Method.

\section{The wet sieving method}

Fifty grams of soil samples were weighed and placed in the glass and added with $500 \mathrm{ml}$ of aquadest. Then it was stirred until homogenized and placed on a series of test sieves $(710 \mu \mathrm{m}, 250$ $\mu \mathrm{m}, 125 \mu \mathrm{m}, 75 \mu \mathrm{m}$ dan $63 \mu \mathrm{m}$ (Brundrett et al., 1996)). The samples taken from $125 \mu \mathrm{m}, 75 \mu \mathrm{m}$ and $63 \mu \mathrm{m}$ were then placed in petridish and ready for observation.

\section{Isolation of arbuscular mycorrhiza spores}

The samples in the petridish was placed under stereo microscope and observed. The spores were taken using micropipette and place into empty petridish. Spores were isolated based on their color (yellow, red, brown, light brown and blackish brown) and counted the number of spores based on the colour (Brundrett et al., 1996).

\section{Identification of arbuscular mycorrhiza spores}

Isolated arbuscular mycorrhiza fungal spores were then placed on object glass, added with Melzer solution. After 1 minute, it was covered with cover glass and squashed so that the solution can enter into the spores (Hermawan et al., 2015). It was then observed the changes in color, subtending hyphae, bulbous suspensor spore surface structure, and spore walls. The morphological identification was conducted using INVAM (2017).

\section{Soil chemical analysis}

The soil chemical analysis was carried out to determine the available $\mathrm{P}$ content, total $\mathrm{P}$, organic $\mathrm{C}$, total $\mathrm{N}$, and $\mathrm{pH}$. One hundred grams of soil samples (mineral soil and peat soil) were analyzed at Soil Laboratory at BALITTRA (Balai Penelitian Pertanian Lahan Rawa) Banjarbaru.

\section{Research Design and Analysis}

We used the survey method in this research. There were 36 soil samples (18 soil samples from mineral soil and 18 soil samples from peat soil). The data was analyzed using T-test to determine the trend and spore comparison between sengon grown on mineral soil and peat soil.

\section{RESULTS AND DISCUSSION}

\section{Sengon trees dimension and soil nutrient content}

The age of sengon trees grown in peatland and mineral soils were $1.5-2$ years. However, the average diameter dimension was different between sengon grown on peatland and mineral soils. The sengon dimension and environmental parameters, such as temperature and humidity, are presented in Table 1.

Sengon trees grown in mineral soils were more prominent in diameter than those in peat soil (9.1$14.5 \mathrm{~cm}, 4.1-7.0 \mathrm{~cm}$, respectively). However, in terms of the height dimension, they were not significantly different. The soil nutrient content is presented in Table 2 .

Table 1. Sengon tree dimension and environmental variables

\begin{tabular}{cccccc}
\hline $\begin{array}{c}\text { Soil } \\
\text { Type }\end{array}$ & $\begin{array}{c}\text { Temperature } \\
\left({ }^{\circ} \mathrm{C}\right)\end{array}$ & Humidity $(\%)$ & $\begin{array}{c}\text { Diameter } \\
(\mathrm{cm})\end{array}$ & $\begin{array}{c}\text { Height } \\
(\mathrm{m})\end{array}$ & Age \\
\hline Peat & $39.0-43.2^{\circ} \mathrm{C}$ & $45-49 \%$ & $4.1-7.0 \mathrm{~cm}$ & $4.5-6 \mathrm{~m}$ & \multirow{2}{*}{$1.5-2$ years } \\
\hline Mineral & $36.0-38.5^{\circ} \mathrm{C}$ & $37-45 \%$ & $9.1-14.5 \mathrm{~cm}$ & $4.5-5 \mathrm{~m}$ & \\
\hline
\end{tabular}

Table 2. Soil nutrient content

\begin{tabular}{|c|c|c|c|c|c|c|c|}
\hline \multirow[t]{2}{*}{ Soil type } & $\mathrm{pH} \mathrm{H}_{2} \mathrm{O}$ & $\mathrm{pH} \mathrm{KCl}$ & C-Org & $\mathrm{N}$ & \multirow{2}{*}{$\begin{array}{c}\text { Available P } \\
(\mathrm{ppm} P)\end{array}$} & $\mathrm{P}$ & K \\
\hline & & & & & & \multicolumn{2}{|c|}{ Total } \\
\hline Mineral & 4.30 & 3.82 & 1.25 & 0.07 & 2.19 & 13.21 & 0.80 \\
\hline Peat & 3.20 & 1.72 & 53.46 & 0.95 & 19.35 & 7.36 & 10.94 \\
\hline
\end{tabular}


The soil chemical properties under sengon trees, both grown in peat and mineral soil, were categorized as low $\mathrm{pH} /$ acidic soil $<6$. However, from the C-organic content, peat soil has a much higher carbon because it was formed of decomposed carbon materials. In terms of $\mathrm{N}$ content, peat soil also has a higher $\mathrm{N}$ content compared with mineral soil. Peat soil also had bigger available $\mathrm{P}$ compared with mineral soil. Nevertheless, $\mathrm{P}$ total was lower in peat soil compared with mineral soil. Mosse and Hepper (1974) stated that $\mathrm{P}$ in the soil available in the form of organic $\mathrm{P}$ and inorganic $\mathrm{P}$. In the condition where $\mathrm{P}$ is not available, colonization is formed faster due to arbuscular mycorrhiza function to change the $\mathrm{P}$ into more available for plant's roots. Solaiman et al., (2014) explained that in the arbuscular mycorrhiza association, nutrient change between fungi and host plants is the most important function. Phosphate acquisition through arbuscular mycorrhiza was started with the absorption of available $\mathrm{P}$ by hyphae. The hyphae were extending beyond the host plant rhizosphere and increase the $\mathrm{P}$ absorption by the plant's roots. Moreover, in terms of C-organic content, Nurhayati (2012) and Sinaga et al. (2015) concluded that the organic material content profoundly influenced arbuscular mycorrhiza colonization in soil.

Although arbuscular mycorrhiza was found in a non-specific host plant, the number of populations diverse and profoundly affected by plant host characteristics and environmental factors such as soil $\mathrm{pH}$, soil humidity, $\mathrm{P}$ content, and $\mathrm{N}$ content. Nursanti et al. (2012) added that arbuscular mycorrhiza distribution diverse following diverse environment.

\section{Arbuscular mycorrhiza colonization on sengon roots}

Arbuscular mycorrhiza colonization on sengon roots is presented in Figure 1. There was a significant difference between AMF colonization in peat soil and mineral soil $(p<0.05)$. AMF colonization on sengon roots grown in peat soil was significantly higher than those grown in mineral soil.

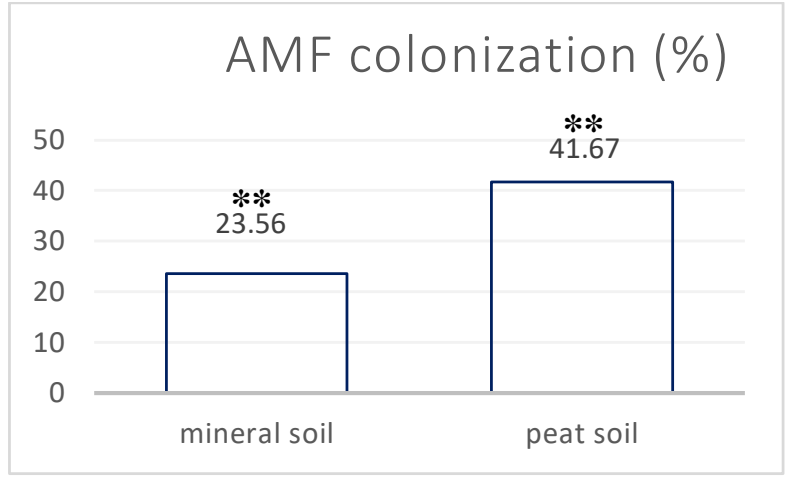

Figure 1. Mean arbuscular mycorrhiza colonization on roots of sengon grown on mineral soil and peatland. Asterix showed significant differences in the T-test $(\mathrm{p}<0.05)$

According to Hermawan et al. (2015), the pH condition in peat soil is more acidic, and AMF is categorized as archidophylic ( fond of acid condition). AMF colonization of more than $30 \%$ can be categorized as high (Yuwati et al., 2016). The structure of AMF colonization on sengon roots grown in peat soil and mineral soil was presented in Figure 2.
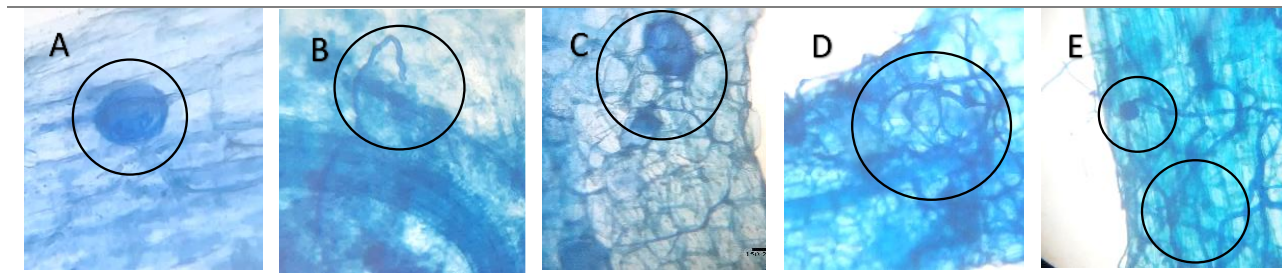

Figure 2. AMF structure colonization on sengon roots ( A. AMF vesicle on sengon root grown in mineral soil, B internal hyphae on sengon roots grown in mineral soil, C. AMF vesicle on peat soil, D, internal hyphae on sengon roots grown in peat soil, E. internal hyphae and AMF spore on sengon roots grown in peat soil) 
The observation on sengon roots grown both in peat soil and mineral soil showed AMF colonization. The colonization was in the structure of hyphae, vesicles, and spores. Simarmata (2007) explained that arbuscular mycorrhiza fungi formed hyphae and will go into the root cell cortex and formed vesicle.

\section{Arbuscular mycorrhiza spore density}

Arbuscular mycorrhiza spore density on mineral soil and peat soil is presented in Figure 3. There was a significant difference between spore density on mineral soil and peat soil $(\mathrm{p}<0,05)$. However, there was no significant difference between 0-30 $\mathrm{cm}$ and 30-60 depth (Figure 4).

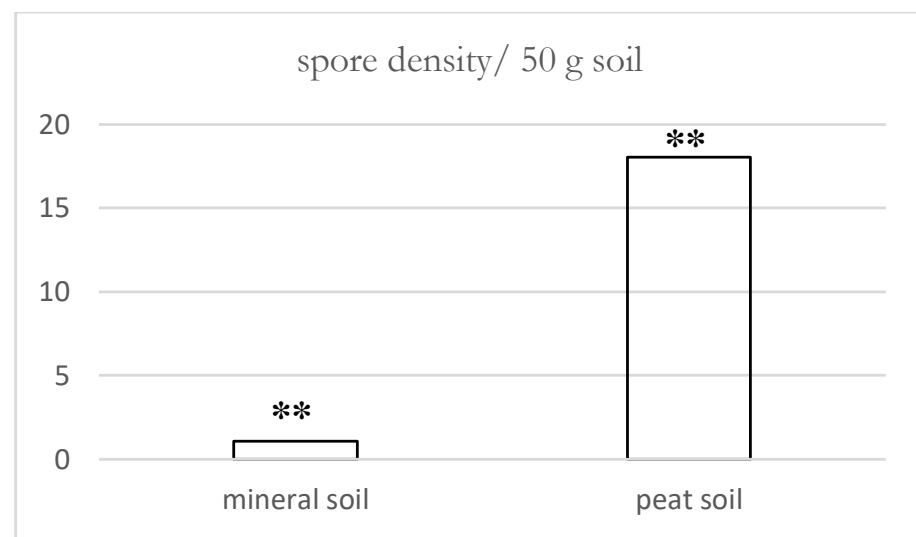

Figure 3. Arbuscular mycorrhiza spore density on mineral soil and peat soil. Asterix showed significant differences in the T-test $(\mathrm{p}=0.00<0.05)$

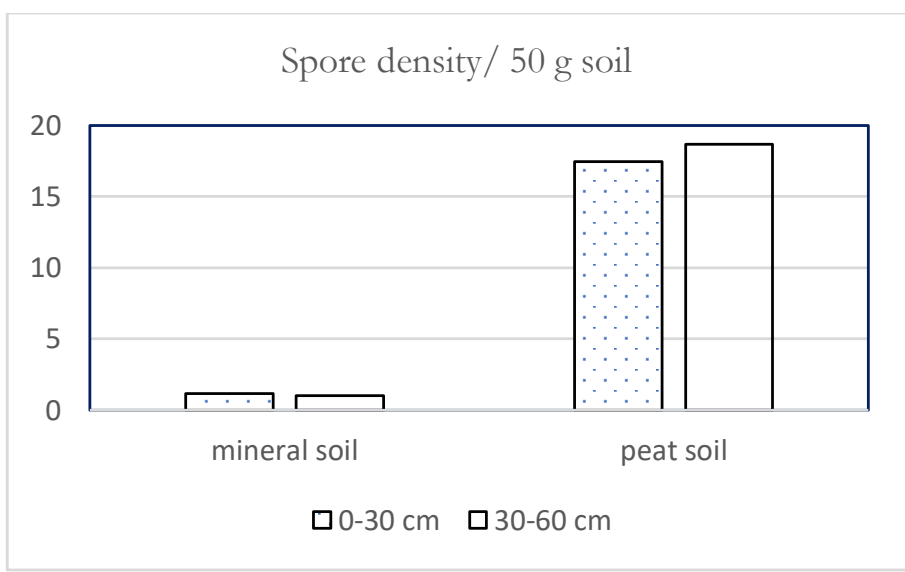

Figure 4. Average arbuscular mycorrhiza spore density per $50 \mathrm{~g}$ soil at two soil depth $(0-30 \mathrm{~cm}$ and $30-60 \mathrm{~cm})$. No significant differences between soil depth $(\mathrm{p}>0.05)$

Nurhidayati et al. (2014) mentioned that soil with high nutrient content owns a low diversity of arbuscular mycorrhiza. When the nutrient status is sufficient for the plants, the plant's roots play roles as absorption organs. This condition caused a negative response to the colonization of arbuscular mycorrhiza spores. Figure 3 showed that there was a significant difference in spore density between mineral soil and peat soil. The abundance of arbuscular mycorrhiza spores and colonization was highly influenced by soil and climatic factors. 


\section{Morphological Identification of Arbuscular Mycorrhiza Spores}

The identification of arbuscular mycorrhiza spores in mineral soil is presented in Figure 5.
Morphological identification of arbuscular mycorrhiza spores under sengon grown in peat soil is presented in Figure 6.

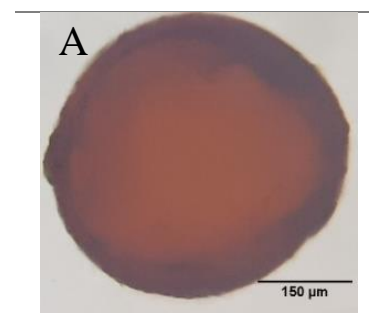

Scutellospora

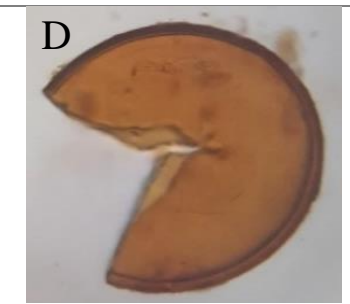

Scutellospora

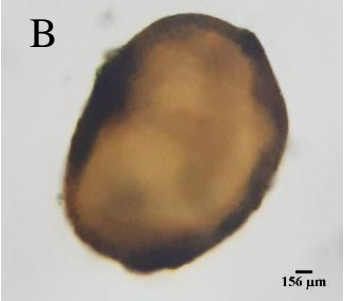

Glomus sp.

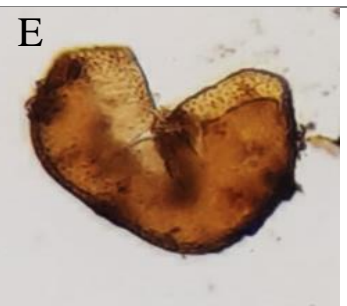

Glomus sp.

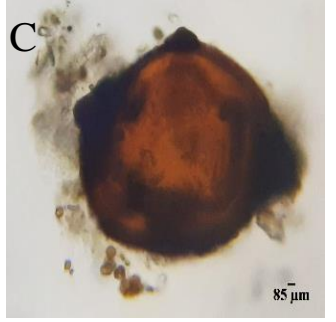

Acaulospora

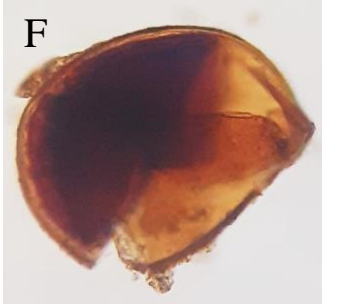

Acaulospora

Figure 5. Arbuscular mycorrhiza spores under sengon grown on mineral soils (A-C before Melzer's application); (D-F After Melzer's application).

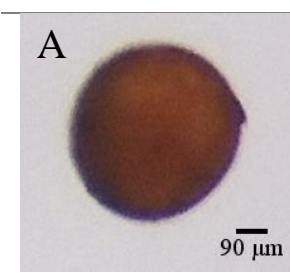

Acaulospora

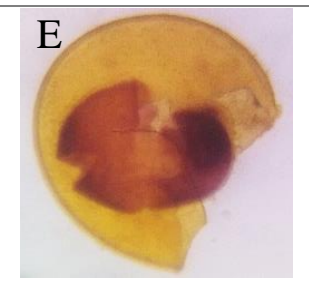

Acaulospora

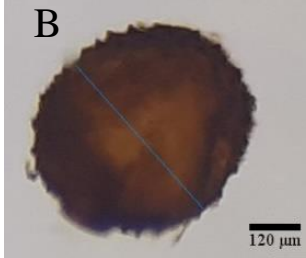

Gigaspora

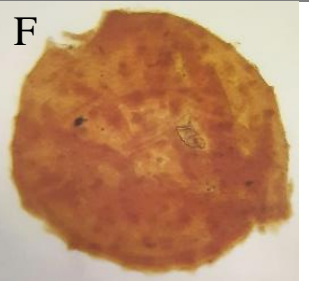

Gigaspora

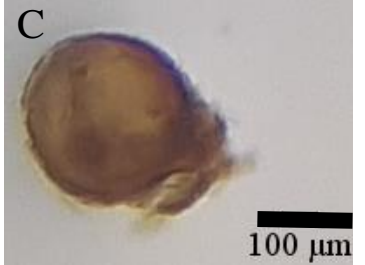

Glomus sp.

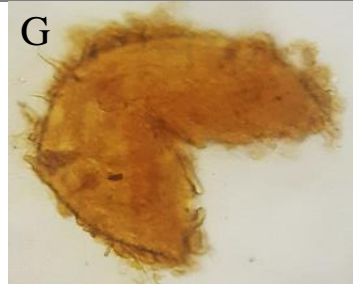

Glomus sp.

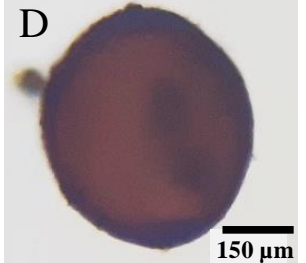

Scutellospora

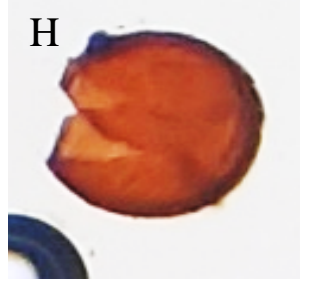

Scutellospora

Figure 6. Arbuscular mycorrhiza spores under sengon grown in peat soil (A-D before Melzer's application); (E-H After Melzer's application).

Based on morphological identification of arbuscular mycorrhiza spores, there were four genus found on peat soil namely Glomus, Gigaspora, Scutellospora, and Acaulospora while there were only three genus found in mineral soil including Glomus, Scutellospora, and Acaulospora. There were no significant differences in terms of size, form, and color, however, the highest abundance of arbuscular mycorrhiza spores found in both soils was Glomus sp. 


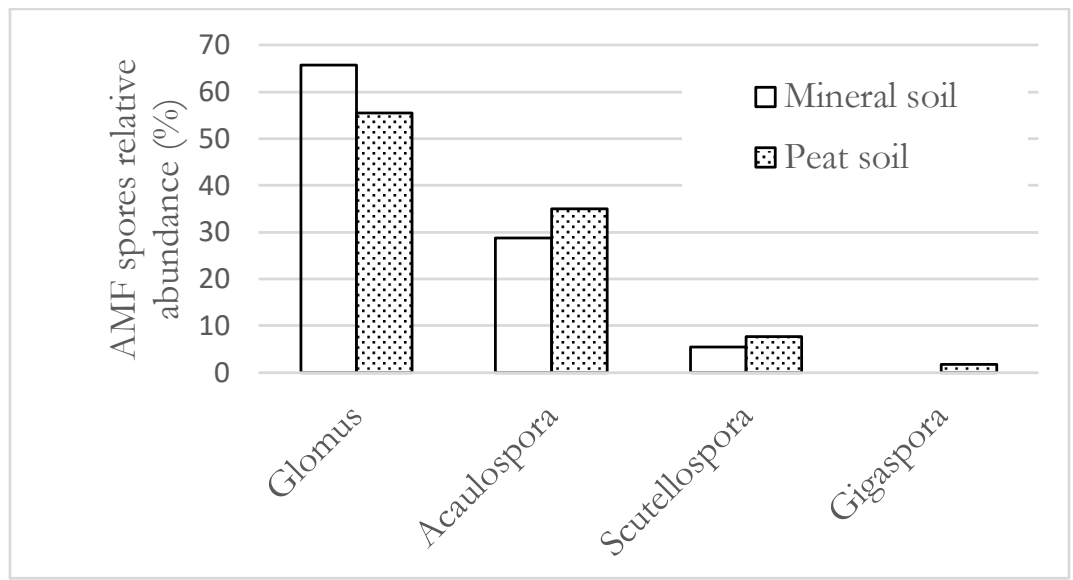

Figure 7. AMF spores relative abundance under sengon grown on mineral soil and peat soil

Glomus was the highest AMF spores relative abundance under sengon grown on mineral soil and peat soil. It showed that Glomus has a high distribution level and high adaptability compared with another genus. As Ramadhani (2007) stated, Glomus can form an association and broader adaptability. This result supported the study of Yuwati and Hakim (2018), Yuwati and Putri (2020), Yuwati et al. (2020), and Hermawan et al. (2015). Moreover, from the study of Sundari (2011), Glomus was the most dominant out of 37 AMF species spores; 25 species were Glomus.

\section{CONCLUSION}

This research concluded that the AMF spore abundance and AMF colonization was higher under sengon grown in peat soil than mineral soil. The AMF spore genus found under sengon grown in mineral soil and peat soils were 3 (Glomus, Scutellospora, and Acaulospora) and 4 (Glomus, Gigaspora, Scutellospora, and Acaulospora), respectively. Glomus was the most dominant genus found in both soil. AMF colonization structure found in mineral soil were vesicles and internal hyphae, while in peat soil were vesicles, internal hyphae, and spores.

\section{REFERENCES}

Augé, R.M. (2001). Water relations, drought and vesicular-arbuscular symbiosis. Mycorrhiza 11: 3-42
Baskorowati, L. 2014. Budidaya Sengon Unggul (Falcataria moluccana) Untuk Pengembangan Hutan Rakyat. IPB Press, Jakarta.

Brundrett, M. C,. N. Bougher,. B. Dells,., T. Grove., \& N. Malajozuk. 1996. Working with mycorrhizas in forestry and agriculture Australian Centre for International Agricultural Research, Canberra.

Brundrett, M., Bougher, N., Dell, B., Grove, T. and Malajczuk, N (1996) Working with mycorrhiza in forestry and agriculture, ACIAR.

Dell B. (2002) Role of mycorrhizal fungi in ecosystems. CMVJ 1:47-60

Harley, J. L. dan Smith, S. E. 1983. Mycorrhizal Symbiosis. Academic Press. London.

Hermawan, H. A. Muin., \& R. S. Wulandari. 2015. Kelimpahan Fungi Mikoriza Arbuskula (FMA) pada Tegakan Ekaliptus (Eucalyptus pellita) berdasarkan Tingkat Kedalaman di Lahan Gambut. Jurnah Hutan Lestari. 3(1) : 124-132

Husna, F. D. Tuheteru \& Mahfudz. 2007. Aplikasi Mikoriza Untuk Memacu Pertumbuhan Jati Di Muna. Info Teknis. 5 (1): 1-4.

INVAM [International Culture Collection of (Vesicular) Arbuscular Mycorrhizal Fungi]. 2017. International culture collection of 
(vesicular) arbuscular mycorrhizal fungi. [terhubung berkala]. [May 2019].

Krisnawati H, Varis E, Kallio M, Kanninen M. 2011. Paraserianthes falcataria (L.) Nielsen: ecology, silviculture, and productivity. CIFOR, Bogor, Indonesia.

Mosse, B., \& Hepper, C. 1974. Vesiculararbuscular mycorrhizal infections in root organ cultures. Physiological Plant Pathology, 5(3): 215-223.

Nurbaity, A., D. Herdiyantoro \& O. Mulyani. 2009. Pemanfaatan Bahan Organik Sebagai Bahan Pembawa Inokulan Fungi Mikoriza Arbuskula. Jurnal Biologi. 8 (1): 11-17.

Nurhayati. 2012. Infektivitas Mikoriza Arbuskula pada berbagai Jenis Tanaman Inang dan Beberapa Jenis Sumber Inokulum. Universitas Syiah Kuala Darussalam, Banda Aceh.

Nurhidayati,T., K. I. Purwani, \& D. Ermavitalini.2014. Isolasi Mikoriza Vesikular-Arbuskular Pada Lahan Kering Di Jawa Timur. Berk. Penel. Hayati Edisi Khusus:43-46.

Nursanti, Tamin, RP \& Hamzah, 2012, Identifikasi Fungi Mikoriza Arbuskular (FMA) Di Hutan Lindung Mangrove Pangkal Babu Kabupaten Tanjung Jabung Barat Jambi. Jurnal Penelitian Universitas Jambi Seri Sains. 14(2): 29-34

Plassard C, Dell B (2010) Phosphorus nutrition of mycorrhizal trees. Tree Physiol 30:11291139

R.-J. Liu and X.-S. Luo. 1994. A New Method to Quantify the Inoculum Potential of Arbuscular Mycorrhizal Fungi. The New Phytologist Vol. 128, No. 1 (Sep., 1994), pp. 89-92.

Rillig M.C. (2004) Arbuscular mycorrhizae and terrestrial system processes. Ecology Letters 7:740-754

Sheng M, Tang M, Chen H, Yang B, Zhang F \& Huang Y. (2009). Influence of arbuscular mycorrhizae on the root system of maize plants under salt stress. Can J Microbiol, 55, pp. 879-886. doi:10.1139/W09-031

Simarmata, T. 2007. Revitalisasi Kesehatan Ekosistem Lahan Kritis Dengan Memanfaatkan Pupuk Biologis Mikoriza Dalam Percepatan Pengembangan Pertanian Ekologis Di Indonesia. VISI.15(3): 289-306.

Sinaga, M. I. A., H. Guchi \& A. Lubis. 2015. Hubungan Ketinggian dan C-Organik Tanah dengan Infeksi FAM pada Tanaman Kopi (Coffea Sp.) di Kabupaten Dairi. Jurnal Agroekoteknologi. 3(4): 157-1584.

Solaiman, Z. M., L. K. Abbott \& A. Varma. 2014 Mycorrhizal Fungi: Use in Sustainable Agriculture and Land Restoration.University Uttar Pradesh, India.

Vierheilig H., Coughlan A.P., Wyss U.R.S and Piche Y. 1998. Ink and Vinegar: A Simple Staining Technique For Arbuscular Mycorrhizal Fungi. Applied and Environmental Microbiology. 64: 50045007.

Yuwati, T. W. \& S. S. Hakim. 2018. Status Asosiasi Fungi Mikoriza Arbuskula Pada Akar Tanaman Sengon (Falcataria moluccana) Di Lahan Gambut Dangkal Liang Anggang Kalimantan Selatan. Galam. 4(2): 35-42.

Yuwati, T.W. and Putri, W.S. 2020. Keragaman Spora Mikoriza Arbuskula Di Bawah Tanaman Shorea balangeran (Korth.) Burck. Sebagai Bio-Indikator Keberhasilan Revegetasi. Jurnal Galam Vol 1 No 1.

Yuwati, T.W., Rahmi, A.N.R., Hakim, S.S. and Badruzsaufari. 2020. The Abundance of Arbuscular Mycorrhiza Infective Propagules Under Galam Stand at Shallow Peat of South Kalimantan. BIO Web of $\begin{array}{llll}\text { Conferences } & 20, & 03008 & \text { (2020). }\end{array}$ https;//doi.org/101051/bioconf/200202003 008 